\title{
Erratum
}

\section{TRAIL PHEROMONE OF THE LEAF-CUTTING ANT, Acromyrmex octospinosus (REICH), (FORMICIDAE: MYRMICINAE)}

JOHN H. CROSS, ${ }^{1,2}$ JANET R. WEST, ${ }^{1}$ ROBERT M. SILVERSTEIN, ${ }^{1}$ ALAN R. JUTSUM, ${ }^{3,4}$ and J. MALCOLM CHERRETT. ${ }^{3}$

\author{
'SUNY College of Environmental Science and Forestry \\ Syracuse, New York 13210 \\ ${ }^{2}$ Monsanto Company, P.O. Box 711 , Alvin, Texas 77511 \\ ${ }^{3}$ University College of North Wales \\ Bangor, Gwynedd, Wales LL57 2UW, U.K.
}

At top of p. 1120, add a $\mathrm{CH}_{3}$ group to $\mathrm{C}-4$ of structure $\mathrm{I}$.

\section{REFERENCE}

Cross, J.H., West, J.R., Silverstein, R.M., Jutsum, A.R., and Cherrett, J. M. 1982.J. Chem. Ecol. 8:1119-1124. 